\title{
Akut ve Kronik Böbrek Yetmezliğinde Tıbbi Beslenme Tedavisi
}

\author{
Medical Nutrition Treatment in Acute and Chronic Renal Failure
}

\section{Banu Süzen ${ }^{1}$}

Geliş tarihi/Received: 13.02.2018 • Kabul tarihi/Accepted: 19.11.2018

\section{ÖZET}

Böbrekler tüm vücut homeostazında önemli bir rol oynayan organdır. Böbrekler ekstraselüler ortamı, özellikle hücre dışı su ve elektrolitleri düzenler. Böbrek yetmezliği, böbrek işlevlerinin ve glomerül filtrasyon hızının (GFH) azaldığı, biriken üremik toksinlerin tüm sistemi etkilediği klinik durum olarak tanımlanmaktadır. Kronik Böbrek Hastalığı (KBH) dünyada ve Türkiye’de yaygın ve önemli bir halk sağlığı sorunudur. Erken saptandığında sıklıkla önlenebilir veya ilerlemesi geciktirilebilir olmasına karşılık, farkındalığı ve erken tanısı düşüktür. Böbrek yetmezliğinin akut veya kronik olmasına bağlı olarak uygulanan tıbbi beslenme tedavisi hastaların yaşam kalitesini arttırırken, hastalığa bağlı komplikasyonların görülme sıklı̆̆ını, mortalite ve morbidite oranlarının da düşmesini sağlamaktadır. Bu makalede akut böbrek hasarı ve kronik böbrek yetmezliği hastalarında tıbbi beslenme tedavisinin güncel klavuzlar ışığında tartışılmıştır.

Anahtar kelimeler: Kronik böbrek yetmezliği, tıbbi beslenme tedavisi, akut böbrek hasarı, kronik böbrek yetmezliği

\begin{abstract}
Kidneys are the organs that play an important role in whole body homeostasis. Kidney regulate the extracellular environment, espesially water and electrolytes. Kidney function deficiency is defined as the clinical situation in which kidney functions and glomerular filitration rate decreases, and accumulation of uremic toxins effecting the whole system. Chronic kidney disease is common both in Turkey and worldwide and it is an important public health problem. Although it is preventable or its spreading speed can be reduced when diagnosed in early stage, the chance of early diagnosis and awareness are low. The medical nutritional treatments depending on whether the kidney function deficiency is chronic or acute increases the life quality of the patients, and at the same time it decreases the frequency of complications related to the disease, mortality and morbidty rates. This article discusses the medical nutrition therapy in patients with acute renal injury and chronic renal failure based on current guidelines.
\end{abstract}

Keywords: Chronic renal failure, medical nutrition therapy, acute renal injury, chronic renal failure

1. İletişim/Correspondence: Ufuk Üniversitesi Dr. Rıdvan Ege Eğitim ve Araştrrma Hastanesi, Beslenme ve Diyet Ünitesi, Ankara, Türkiye • E-posta: banu.suzen@gmail.com (i) https://orcid.org/0000-0002-5975-5868 


\section{GíRiş}

Böbrekler, tüm vücut homeostazında önemli bir rol oynayan organdır. Böbrekler ekstraselüler ortamı, özellikle hücre dişı su ve elektrolitleri düzenler. Ayrıca, protein metabolizmasindan ve iskelet kasından salınan kreatinden azotlu ürünleri uzaklaştırırlar. Bununla birlikte, böbreklerin kabul edilebilir bir aralık içinde hücre dışı su ve elektrolitleri koruma özelliği, tüm hücreler ekstraselüler ortamda bulunduğu için vücudun tüm organları üzerinde büyük bir etkiye sahiptir (1). Kronik Böbrek Hastalığı (KBH) dünyada ve Türkiye'de yaygın ve önemli bir halk sağlığı sorunudur. Tahmini global prevalansı \%11-13'dür (2). Türkiye'de Kronik Böbrek Hastalığı (Chronic Renal Disease in Turkey, CREDIT) çalışması sonuçlarına göre, 2008 yılında genel yetişkin nüfusta KBH prevalansı \%15.7 olarak saptanmıştır (3). Erken saptandığında sıklıkla önlenebilir veya ilerlemesi geciktirilebilir olmasına karşılık, farkındalığı ve erken tanısı düşüktür. Farkındalığının ve erken tanısının düşük olması nedeni ile böbrek hastalığı Son Dönem Böbrek Yetmezliği (SDBY) evresine ilerlemekte, yüksek morbidite ve mortalite oranları ve kötü yaşam kalitesi ile hasta sağlığını, uygulanması gereken yüksek maliyetli diyaliz ve böbrek nakli tedavileri ile sağlık bütçesini ciddi olarak tehdit etmektedir (4).

Böbrek hastalıklarının ilerleyici olması pek çok komplikasyonu beraberinde getirmektedir. Bunun yanında, beslenme sorunlarının olması böbrek yetmezliğinin daha zor bir hastalık olmasına neden olmaktadır. Tıbbi beslenme tedavisi hem hastalığın ilerlemesini yavaşlatmak hem de hastalığa bağlı mortaliteyi ve morbiditeyi azaltmak amacıla uygulanmakta ve tıbbi tedavinin bir parçası olarak tanımlanmaktadır. Bu derlemede hem akut böbrek yetmezliğinde hem de kronik böbrek yetmezliğinde güncel beslenme yaklaşımları paylaşılacaktır.

\section{Akut Böbrek Hasarında Tıbbi Beslenme Tedavisi}

Akut böbrek yetmezliği (ABY), kısa süre içinde meydana gelen glomerülerfiltrasyon hızında (GFH) ani düşüştür ve böbreğin nitrojen atık ürünleri dışarı atması, sıvı ve elektrolit homeostazisini sürdürememesi ile sonuçlanır. Azotlu atıkların tutulması genellikle kan üre azotu (BUN) ve serum kreatinin ölçümü ile değerlendirilir. Ancak, böbrek hasarından hemen sonra BUN veya kreatinin düzeyleri normal olabilir ve böbrek hasarının tek işareti idrar üretiminin azalmasıdır. Bu tanım, böbrek işlevinde ne zaman ne de kantitatif değişikliklerin belirtilmediği göz önüne alındığında, büyük ölçüde özneldir. $\mathrm{Bu}$ öznel tanım nedeni ile hastalığın prevalansının saptanması ve klinik araştırmaların yapılabilmesi oldukça zor olduğu için son ylllarda ABY terimi "akut böbrek hasarı” (ABH) olarak terminolojiye girmiştir. Bu tanım, böbrek işlevlerinde küçük değişikliklerden böbrek replasman tedavisine gerek duyulan tüm sendromu kapsamaktadır. ABY ise şiddetli $A B H$ için kullanılmaktadır. ABH'nın başlangıç tanımı Akut Diyaliz Kalitesi Girişimi (ADQI) tarafından önerilmiş ve sonrasında Akut Böbrek Hasarı Ağı tarafından renal risk, hasar, yetmezlik, böbrek işlev kaybı, son dönem renal yetmezlik kriterleri olan RIFLE sınıflaması geliştirilmiş sonrasında ortak bir fikir birliği ile Akut Böbrek Hasarı Ağı (AKIN) tarafından $\mathrm{ABH}$ evreleme kriterleri geliştirilmiştir (Tablo 1) $(4,5)$.

Dünya çapında $\mathrm{ABH}$ insidansı, yetersiz bildirim, bölgesel farklılıklar ve tanım farklılıkları nedeniyle bilinmemektedir. Gelişmekte olan ülkelerdeki $\mathrm{ABH}$ epidemiyolojisinin, gelişmiş ülkelerdekilerden çok daha farklı olduğu bilinmektedir. Gelişmiş ülkelerde yaşlı hastalarda, gelişmekte olan ülkelerde gençlerde ve çocuklarda sıklıkla görülmektedir. Gelişmekte olan ülkelerde, ABH'nın en yaygın nedenleri sıklıkla hacim duyarlı prerenal, obstetrik, enfeksiyöz veya toksik mekanizmalarla ilişkilidir. Gelişmiş ülkelerde $\mathrm{ABH}$ seyrek olarak toplum kökenli bir hastalıktır ve bu durum öncelikle hastanede yatan hastalarda gelişir (5). ABH'nın genel toplumda görülme sıklığı \%1'in altında olmasına karşılık, hastanede yatan hastalarda \%2-7, yoğun bakım ünitesinde tedavi edilen hastalarda \%5-30'a kadar artmaktadır (6). Renal replansman tedavisi (RRT) ile tedavi edilen hastalarda mortalite oranını \%50-60'tır. Hayatta kalan hastaların \%5-20'si hastaneden diyaliz endikasyonu ile olmaktadır (5). 
Tablo 1. ABH sinıflandirması- AKIN ve RIFLE sinıflamaları $(4,5)$

\begin{tabular}{|c|c|c|c|}
\hline AKIN evresi & RIFLE sınıflaması & Serum kreatinin & İdrar miktarı \\
\hline 1 & Risk & $>0.3 \mathrm{mg} / \mathrm{dL}$ veya $1.5-2$ kat artış (GRH azalma $>\% 25$ ) & $<0.5 \mathrm{~mL} / \mathrm{kg} / \mathrm{sa} \times \mathrm{x} 6$ saat \\
\hline 2 & Hasar & 2-3 kat artış (GFH’da azalma>\%50) & $<0.5 \mathrm{~mL} / \mathrm{kg} / \mathrm{sa} \times 12$ saat \\
\hline \multirow[t]{3}{*}{3} & Yetmezlik & $\begin{array}{l}>3 \mathrm{~kat} \text { artış veya }>0.5 \mathrm{mg} / \mathrm{dL} \text { artışla birlikte serum } \\
\text { kreatinin }>4 \mathrm{mg} / \mathrm{dL} \text { (GFH'da azalma >\%75) }\end{array}$ & $\begin{array}{l}<0.3 \mathrm{~mL} / \mathrm{kg} / \mathrm{sa} \text { x } 24 \text { saat } \\
\text { veya anüri x } 12 \text { saat }\end{array}$ \\
\hline & Kayıр & Süre giden böbrek yetmezliği $>4$ hafta & \\
\hline & SDBY & Süre giden böbrek yetmezliği $>3$ ay & \\
\hline
\end{tabular}

AKIN: Akut böbrek hasarı ağı; RIFLE: Renal risk, hasar, yetmezlik, böbrek işlev kaybı; SDBY: Son dönem renal yetmezlik; GFH: Glomerular filitrasyon hızı

ABH'nin nedenleri geleneksel olarak üç sinıfa ayrılmaktadır. Bunlar, prerenal nedenler, üriner sistem obstrüksyonları (postrenal nedenler) ve akut intrinsik böbrek hastalıklarıdır. ABH'nın en sık nedeni prerenal yetmezlik (vakaların >\%35’i) ve akut tübüler nekroz (ATN) (vakaların >\%50'si) dur. Obstrüksiyon, vakaların yaklaşık \%10'unu oluşturmaktadır (5).

$\mathrm{ABH}$ seyrek olarak tek başına görülmektedir. Sıklıkla hipotansiyon, sepsis ve çoklu organ yetmezliğinin eşlik ettiği hastalarda görülmektedir. $\mathrm{Su}$ ve elektrolitler üzerindeki etkilerinin yaninda karbonhidrat, protein ve yağ metabolizmaları üzerinde de etkilidir. Bunun yanında antioksidatif sistemi etkileyen proinflamatuvar bir hastalıktır. Kısacası, ABH'lı kritik hastaların metabolik yanıtları sadece bozulmuş böbrek işlevi ile değil, aynı zamanda ciddi enfeksiyonlar ve çoklu organ işlev bozukluğu dahil olmak üzere altta yatan hastalık süreci ve komplikasyonları tarafindan da belirlenir. RRT tipi ve yoğunluğu, metabolizma ve besin ögesi dengeleri üzerinde büyük bir etki yapabilir (7). Bu nedenle, $\mathrm{ABH}$ olan hastalarda tıbbi beslenme tedavisi başlangıçtaki hastalığın şiddetine, böbrek yetmezliğinin düzeyine ve verilen renalreplasman tedavisinin RRT tipine bağlı olarak planlanmaktadır (5).

Metabolik değişikliklerin ABH'daki işareti, iskelet kasından aşırı miktarda aminoasit salan ve böylelikle hepatik glukoneojenez ve ürejezini arttıran protein katabolizmasinın aktivasyonudur. $\mathrm{Bu}$ durum negatif nitrojen dengesine ve somatik protein depolarının kaybedilmesine neden olmaktadır. Artan protein katabolizmasinın yanı sira, protein sentezi süreçlerinde de aminoasitlerin kullanımı bozulur.
$\mathrm{Bu}$ süreçler hem plazma hem de hücre içi hücre sıvısında aminoasit havuzlarında dengesizliklere yol açar. Ek olarak, glukoneojenezi destekleyen çoğu aminoasidin klirensi ABH tarafindan arttırılır. Son olarak, elzem olmayan aminoasitler olarak kabul edilen birkaç aminoasit (örneğin arjinin veya tirozin), metabolizmaları ABH tarafindan değiştirildiği için şartlı elzem aminoasitler haline gelir (7).

$\mathrm{ABH}$ olan hastaların bir kısmı normal beslenebilirken hipermetabolik süreç ile birlikte orta veya ciddi $\mathrm{ABH}$ olan hastalarda besin ögesi gereksinmelerinin karşılanabilmesi için beslenme desteği gerekmektedir. Katabolik süreci ağır ve uzun süren hastalarda malnütrisyon riski yüksektir. Hastaların beslenme durumlarının değerlendirilmesi $\mathrm{ABH}$ olan hastaların birçoğunda zordur ve sıklıkla kullanılan geleneksel beslenme durum saptama yöntemleri akut hastalık, vücut sıvı değişimleri gibi durumlara bağlı olarak yanıltıcı olabilmektedir. Özellikle katabolik sürecin ağır olduğu hastalarda yağsız vücut kütlesi kaybı ve kas proteinlerindeki katabolizmanın yüksek olması yatak başı ölçümler ile doğru değerlendirilememektedir (4). Bunun dışında beslenme durumu saptanması için kullanılan tarama araçları katabolik süreci ağır olan $\mathrm{ABH}$ hastalarında kullanılan subjektif global değerlendirme yoğun bakım hastaların \%40'ında ağır malnütrisyonu göstermektedir (8). Uluslararası Böbrek Beslenme ve Metabolizma Derneği (ISRNM) akut ve kronik böbrek yetmezliğinde beslenme yetersizliği ile ilişkili standartları belirlemişlerdir. Akut ve kronik böbrek yetmezliğinde protein enerji malnütrisyonu terimi yerine metabolik strese bağlı azalan işlevsel kapasite ile protein ve enerji depolarının tükenmesini kapsayan protein-enerji 
tükenmişliği (PEW) kavramını tanımlamışlardır. $\mathrm{ABH}$ olan hastalarda beslenme durumunun planlaması başlangıçta hastanın primer hastalığına göre yapılsa da akut hastalık sürecinde gelişen metabolik komplikasyonlar nedeni ile PEW riski yüksek olan hasta grubudur. Beslenme durumunun bozulması hastanede kalış süresi, enfeksiyon riski, kardiyorespiratuar yetmezlik gibi komplikasyonların ve mortalitenin artmasına neden olmaktadır. ISRNM beslenme durumunu değerlendirmesi için 4 grup kriter kullanımını önermektedir. Bunlar, biyokimyasal ölçümler (serum albümin, prealbümin veya düşük kolesterol), vücut kütlesinde azalma ve kas kütlesinde azalma, azalmış besin alımı ile birlikte ağırlık kaybıdır (5). Bu kriterlerin bir kısmı inflamasyondan, vücut sıvı değişiminden etkilendiği için ek parametre olarak C-reaktif protein (CRP) ve albümin, prealbümin ile birlikte beslenme durumunu değerlendirmesinde yardımcı olabilmektedir (9).

$\mathrm{ABH}$ olan hastalarda besin ögesi gereksinmeleri, altta yatan hastalığın şiddeti, beslenme durumu, komorbid hastalıklar ve RRT göre planlanmaktadır. $\mathrm{Bu}$ kriterler göz önüne alındığında kişiye göre beslenme değerlendirmesi ve planlaması yapılması önerilmektedir. Başlangıçta $\mathrm{ABH}$ ve protein katabolizmasının şiddetine göre hafif, orta ve ağır olmak üzere sinıflandırma yapılması tıbbi beslenme tedavisinin planlanmasında yardımcı olmaktadır (4) (Tablo 2).

Tablo 2. ABH hastaların protein katabolizma derecelerine göre sınıflandırılması ve besin ögesi gereksinmeleri (4)

\begin{tabular}{|c|c|c|c|}
\hline & \multicolumn{3}{|c|}{ Katabolizma derecesi } \\
\hline & Hafif & Orta & Ciddi \\
\hline Aşırı üre oluşumu (>alınan N) & $<5 \mathrm{~g}$ & $5-10 \mathrm{~g}$ & $>10 \mathrm{~g}$ \\
\hline Klinik durumlar & İlaç toksisitesi & \multicolumn{2}{|c|}{ Elektif cerrahi \pm infeksiyonSepsis, ARDS } \\
\hline Mortalite & $\% 20$ & $\% 60$ & $\% 80$ \\
\hline Diyaliz/HF (sıklık) & Seyrek & Gerektiğinde & Sik \\
\hline Beslenme yolu & Oral & \multicolumn{2}{|c|}{ Enteral ve/veya parenteralEnteral ve/veya parenteral } \\
\hline Enerji gereksinmesi (kkal/kg/gün) & 25 & $25-30$ & $25-35$ \\
\hline Enerji kaynağı & Glukoz & Glukoz+yağ & Glukoz+yağ \\
\hline Glukoz (g/kg/gün) & $3-5$ & $3-5$ & $3-5$ \\
\hline Yağ (g/kg/gün) & - & $0.5-1$ & $0.8-1.2$ \\
\hline Aminoasit/protein (g/kg/gün) & 0.6-1 EAA & 0.8-1.2 EAA+NEAA & 1-1.5 EAA+NEAA \\
\hline Beslenme önerileri & Normal besin & & \\
\hline Oral/enteral & & Enteral formüller & Enteral formüller \\
\hline \multirow[t]{4}{*}{ Parenteral } & & Glukoz \%50-70 & Glukoz \%50-70 \\
\hline & & Yağ \%10-20 & Yağ \%10-20 \\
\hline & & AA $\% 6.5-10$ & AA $\% 6.5-10$ \\
\hline & & mikro besin ögeleri & mikro besin ögeleri \\
\hline
\end{tabular}

HF: Hemoflitrasyon, EAA: Elzem aminoasit, NEAA: Elzem olmayan aminoasit

\section{Enerji ve makro besin ögeleri gereksinmesi}

ABH olan hastalarda, hastalığın şiddetine göre besin ögesi ve enerji gereksinmeleri değişmektedir. $\mathrm{ABH}$ olan hastalarda verilecek olan en uygun protein gereksinmesi böbrek hasarının şiddetine göre planlanmaktadır. Aminoasit havuzunda hem plazma hem de hücre içi bileşenleri değişmektedir ve eksojen olarak verilen aminoasitlerin dokularda kullanımı bozulmaktadır. Aminoasit oksidasyonu uyarılırken, kas içine taşınması azalmaktadır. Fenilalanin, metionin, taurin ve sistein gibi aminoasitlerin serum düzeyleri artarken, valin, löysin ve glutamin serum düzeyleri azalmaktadır. Böbrek Hastalığı Küresel Çıktıları İyileştirilmesi K/DOQI Rehber önerisine göre en uygun protein RRT alan hastalarda $1.2 \mathrm{~g} / \mathrm{kg} / \mathrm{gün}$, hemodiyaliz alan hastalarda $1.3 \mathrm{~g} / \mathrm{kg} /$ gün'dür $(10,11)$. 
Hafif ve hipermetabolik olmayan ABH olan hastalarda yapılan çalışmalarda 0.97-1.3 $\mathrm{g} / \mathrm{kg} / \mathrm{gün}$ protein alımının poliürik faz sırasında pozitif azot dengesini sağladığı bildirilmiştir (11,12). Katabolik olmayan ABH hastaların RRT gereksinmesi olmamakta ve böbrek işlevlerini tekrar kazanma ihtimali daha yüksek olmakta ve protein gereksinmesi $0.8 \mathrm{~g} / \mathrm{kg} /$ gün yeterli enerji ile karşılandığında pozitif nitrojen dengesi sağlanmaktadır. Komplike (orta ve ciddi) ABH olan, özellikle RRT alan hastalarda 1.4-1.75 g/kg/ gün (1.5 g/kg/gün) protein alımı önerilirken, $1.7 \mathrm{~g} / \mathrm{kg} /$ gün üzerinde protein alımı önerilmemektedir. Daha yüksek protein alımının daha net pozitif nitrojen dengesini sağladığına yönelik kanıtlat yeterli değildir. Önerilenden yüksek protein alımının azotlu ara ürünlerin birikmesine neden olabilmektedir $(5,11)$.

ABH olan hastalarda enerji harcaması, altta yatan hastalık ve komplikasyonlar ile belirlenmektedir. KomplikeolmayanABHolanhastalardaoksijentüketimi sağlıklı bireyler ile benzerdir. Komplike ABH (sepsis veya çoklu organ yetmezliği) olan hastalarda oksijen tüketimi bazal enerji harcamasının \%20-30’u kadar artmaktadır. Bugüne kadarki $\mathrm{ABH}$ olan hastalarda yapılan çalışmalarda, Harris-Benedict denklemi ile hesaplanan en yüksek metabolik enerji harcamasının normalin \%130 olduğu bildirilmiştir (13). RRT alan hastalarda yapılmış bir gözlemsel çalışmada $25 \mathrm{kkal} /$ $\mathrm{kg} /$ gün enerji ve $1.5 \mathrm{~g} / \mathrm{kg} / \mathrm{gün}$ protein alan hastalarda nitrojen dengesinin sağlanması için enerjinin yeterli olmadığı gözlemlenmiştir (14). Protein alımının 1.5 g/ $\mathrm{kg} /$ gün enerji gereksinmesinin $40 \mathrm{kkal} / \mathrm{kg}$ gün olarak karşılanmasının pozitif nitrojen dengesinde düşük enerjiye göre anlamlı sonuçlar vermiş ancak $30 \mathrm{kkal} /$ $\mathrm{kg} /$ gün üzerinde enerji verilmesinin beslenmenin metabolik komplikasyonlarına neden olabileceği bildirilmiştir (15). Diyaliz alan 60 yaş altı hastalar için en uygun enerji gereksinmesi $35 \mathrm{~kg} / \mathrm{kg} /$ gün, 65 yaş üstü hastalar için $35 \mathrm{~kg} / \mathrm{kg} /$ gün ve altı olarak K/DOQI rehberlerinde önerilmiştir (10).

İnsülin direnci ve böbrek işlev kaybı nedeni ile hiperglisemi sıklıkla görülmektedir. Böbrekler insülinin yıkım ürünlerinin atılması için temel organlar oldukları için böbrek hasarında insülin yıkımı ve hepatik insülin katabolizması azalmaktadır. Periferik glukoz intoleransı ve artmış glikoneogenez görülmektedir. $\mathrm{ABH}$ olan hastalarda hepatik glikoneogenez ekzojen glukoz infüzyonu ile baskılanmamaktadır. Bu nedenle karbonhidratlar temel enerji kaynağı olarak kullanılmaktadır. Nonprotein enerjinin büyük bölümü karbonhidrat kaynaklarından sağlanmaktadır. Hiperglisemi riski nedeni ile sıkı kan şekeri ölçümleri yapılması önerilmektedir $(11,16)$.

Böbrek işlevlerindeki bozulma nedeni ile plazma trigliserit ve çok düşük yoğunluklu lipoprotein (VLDL) kolesterol düzeyleri artarken, total kolesterol, yüksek yoğunluklu lipoprotein (HDL) ve düşük yoğunluklu lipoprotein (LDL) düzeyleri düşüktür. Bozulmuş lipaz, dengesiz plazma lipit düzeylerinin en önemli nedenidir. Lipoproteinlipaz ve hepatik trigliserit lipaz aktivitesi $\mathrm{ABH}$ olan hastalarda \%50 azalmaktadır. Lipitlerin parenteral olarak verilmesinden sonra lipit klirensi azalmaktadır. Lipit emülsiyonlarının metabolizması endojen VLDL metabolizmasına benzemektedir, böylece lipit emülsiyonları ABH'da klirensi, özellikle uygulama hızı yüksek olduğunda yavaşlamaktadır. Ekzojen lipit partiküllerinin plazmada temizlenme oranının düşmesine rağmen, yağ asidi oksidasyonu korunmaktadır. Bu nedenle ikinci önemli enerji kaynağı olarak lipitler kullanılmaktadır. Non-protein enerjinin \%30-35’i lipitlerden karşılanmalıdır. Parenteral beslenmede \%10-30’luk lipit emülsiyonu içeren üçü bir arada hazır parenteral beslenme ürünleri ya da 0.8-1.2 g/kg/gün lipit verilmesi önerilmektedir. Lipit emülsiyonlarının hangisinin daha etkili ve yararlı olduğuna dair kanıtlar yetersizdir (4).

\section{Mikro besin ögesi gereksinmesi}

$\mathrm{ABH}$ olan hastalarda mineral ve vitamin gereksinmelerine yönelik çok az çalışma vardır. Çalışmalar genel olarak kronik böbrek yetmezliği olan hastalar ile yapılmıştır. ABH olan RRT alan hastalarda yapılmış olan çalışmalarda normalin altında C vitamini, tiamin ve folik asit düzeyleri gözlemlenmiştir $(17,18)$. Komplike olmayan ABH olan hastalarda mikro besin ögesi gereksinmeleri, altta yatan hastalita dikkate alınarak, kontrol edilerek verilmelidir. RRT 
alan komplike $\mathrm{ABH}$ olan hastalarda kayılar, diyaliz tedavisinin etkisiyle daha fazladır. RRT çeşidine, süresine göre kayıplar değişmekte ve vitamin kayıpları için net veriler yoktur. Rehber önerilerinde potasyum, magnezyum, fosfor ve kalsiyum serum düzeyleri izlenerek destek yapılmalıdır. RRT alan ABH olan hastalara günlük $1 \mathrm{mg}$ folat, $10 \mathrm{mg}$ pridoksin, $100 \mu \mathrm{g}$ selenyum, $100 \mathrm{mg} C$ vitamini desteği önerilmektedir. Parenteral beslenme desteği alan hastalarda suda çözünen vitaminlerin ekstra eklenmesi enteral beslenme desteği alan hastalarda kontrollü eklenmesi uzmanlar tarafından önerilmektedir (13).

\section{Kronik Böbrek Yetmezliği (KBY)}

Renal parankimal hastallk, nefron kaybina ve ardından kalan nefronlarda adaptif hiperfiltrasyona yol açabilen çeşitli akut ve kronik olayların sonucudur. $\mathrm{Bu}$ adaptif hiperfiltrasyon, proteinüri ve progresif böbrek işlev kaybına yol açan uzun süreli glomerüler hasarla sonuçlanır. Böbrek işlevinin ilk düşüşü asemptomatiktir ve böbrek yetmezliğinin klinik belirtileri hastalığın seyri boyunca geç görülür. Bununla birlikte, böbrek işlev kaybı değişkendir ve en uygun tıbbi tedaviye rağmen ilerleyebilir. Bu nedenle böbrek hastalığının tanımları, fonksiyon ölçütlerine glomerüler filtrasyon hızı (GFH) ve hasar ölçütlerine (proteinüri, anatomik anormallikler) odaklanmıştır (19). Diyabet, KBH için önde gelen risk etmenidir ve bunu hipertansiyon, glomerülonefrit, polikistik böbrek hastalığı, konjenital anomaliler ve diğer hastalıklar izler (20).

Kronik böbrek hastalığı, temelde yatan böbrek hastalığının etyolojisi ne olursa olsun en az üç ay süren objektif böbrek hasarı [GFH'nin azalması olsun ya da olmasin] ve/veya GFH'nin $60 \mathrm{~mL} /$ dakika/1.73 m²nin altına inmesi durumu olarak tanımlanmaktadır (21).

Kılavuzlar ayrıca KBY'nin sinıflandırılması için beş evreli bir sistem tanımlamışlardır. Evre 1 ve 2, böbrek hasarı belirteçlerinin varlığı ile tanımlanır ve hafif azalmış GFH Evre 1 ve biraz daha azalmış GFH Evre 2 ile birbirinden ayırt edilir. Üç ila beş arasındaki evreler yalnızca GFH düzeyine dayanır. Evreleme sistemi, GFH'nin azaldığı ve altta yatan böbrek hastalığının etiyolojisinden bağımsız olarak ortaya çıkabilecek (glomerülonefrit veya hipertansif nefro skleroz gibi) hiperparatiroidizm gibi azalmış böbrek işlevlerini tanımlamakta ve artan azotemik yükünü temsil etmektedir. KBH'nin her aşamasında, hastalarda sonuçları iyileştirmek ve en iyi, ancak genellikle sinırl, mevcut kanitlara dayanarak mortaliteyi azaltmak amaciyla bir eylem planı uzmanlar tarafindan önerilmiştir. The National Kidney Foundation Kidney Disease Outcomes Quality Initiative K/DOQI sinıflandırma sistemi klinik özelliklere (nefrotik sendrom gibi) veya patofizyolojik mekanizmalara (böbrek biyopsisinde immünoglobulin A (IgA) nefropatisi) dayanan geleneksel sinıflandirma sistemlerini tamamlamaktadır (19,22) (Tablo 3).

Tablo 3. K/DOQI siniflandırma sistemi (22)

\begin{tabular}{lll}
\hline GFH evreleri & GFH $\left(\mathbf{m L} /\right.$ dakika/1.73 $\left.\mathbf{~ m}^{\mathbf{2}}\right)$ & Tanımlar \\
\hline G1 & $>90$ & Normal veya yüksek \\
G2 & $60-89$ & Hafif azalmış \\
G3a & $45-59$ & Hafif-orta derece azalmış \\
G3b & $30-44$ & Orta-şiddetli derecede azalmış \\
G4 & $15-29$ & Şiddetli azalmış \\
G5 & $<15$ & Böbrek yetmezliği \\
\hline Albüminüri evreleri & AER (mg/gün) & Tanımlar \\
\hline A1 & $<30$ & Normal/yüksek normal \\
A2 & $30-300$ & Yüksek \\
A3 & $>300$ & Çok yüksek \\
\hline
\end{tabular}

AER: Albümin atım oranı 


\section{Kronik Böbrek Yetmezliğinde Tıbbi Beslenme Tedavisi}

Tıbbibeslenmetedavisi(TBT),kronikböbrekyetmezliği olan hastalarda beslenme durumunun korunması ve/veya geliştirilmesi, hastalığın progresyonunun yavaşlatılması, metabolik patolojilerin önlenmesi, üremik toksinlerin ve vasküler hastalıkların azaltılmasını amaçlamaktadır. Beslenme müdahalesi, temel beslenme eğitimi ve tıbbi beslenme tedavisini içermektedir. KBY Evre 1-3 için TBT'nin hedefleri, iyi bir beslenme durumunun sürdürülmesini, böbrek yetmezliğinin ilerlemesini geciktirmeyi ve komorbiditeler için risk etmenlerini azaltmayı içerir. TBT, protein-enerji malnütrisyonunu ve mineral ve elektrolit bozukluklarını önler ve/veya tedavi eder, diyabet, hipertansiyon ve lipit metabolizması bozuklukları gibi diğer komorbiditelerlerin böbrek hastalığının ilerlemesi üzerindeki etkisini en aza indirir. K/DOQI kuralları, KBH olan bireylerin beslenme durumlarının düzenli aralıklarla (örneğin, 1 ile 3 aylık aralıklarla) izlenmesini önermektedir (23). KBY hastalarında TBT'nin etkinliği üzerine yapılan bir araştırma antropometrik ve biyokimyasal ölçümlerde önemli gelişmeler olduğunu bildirmiştir (24).

Beslenme ve azalan böbrek işlevleri arasındaki bağlantı Richard Bright'ın ödem ve proteinüriyi geçici olarak tedavi etmek için sütle beslenmeyi önerdiği 1800'lü yılların ortalarında ortaya çıkmıştır. Son derece kısitlı olan bu diyetler yirminci yüzyıla kadar kullanılmıştır (25). Fitz Bischoff (1932), diyet ve böbrek arasındaki bağlantıyı doğrulayan ilk bilimsel açıklamalardan birini gerçekleştirmiştir (25). Hayvanlar üzerinde yapılan çeşitli çalışmalardan sonra nefrotoksik etmenlerin diyet alımının bir sonucu olabileceği gösterilmiştir (25). Üremik toksisiteyi en aza indirmek ve böbrek işlev kaybını geciktirmek için kısıtlı diyet uygulamaları halen devam etmektedir. Kronik böbrek yetmezliği hastalarında klasik anlayış, serum BUN, GFH, kareatinin ve elektrolit düzeylerine göre kısıtlamalı diyet önerilmesidir. Ancak önemli olan KBY hastalarına önerilen kisıtlı diyetlerin hastalar tarafindan uygulanabilir ve sürdürülebilir olmasıdır. KBH hastalarında düşük proteinli diyete esnek ve yenilikçi yaklaşımının ana hedefi, düşük proteinli diyet programının başarılı bir şekilde uygulanmasında önemli bir etmen olan hasta uyumu iyileştirilmesidir (26). Bu nedenle hastalar için verilen temel rehber önerilerin yanında beslenme eğitimi ve hastanin beslenme izleminin yaplabilmesinde diyetisyeninönemibüyüktür. Diyetplanlamasıhastaya anlatılırken görsel ögelerden yararlanarak beslenme eğitimi verilmesi, kontrollerde beslenme eğitiminin aynı şekilde tekrarlanması hastanın diyet uyumunu kolaylaştırırken, beslenme davranışlarındaki olumlu değişimi de sağlamaktadır (27).

\section{Enerji ve makro besin ögesi gereksinmesi}

Düşük proteinli diyetler, proteinüriyi azaltmada, kronik böbrek hastalığının bulgularını, semptomlarını ve komplikasyonlarını düzeltmede ve önlemede, diyaliz başlangıcını geciktirmede, yetersiz beslenmeyi önlemede ve kardiyovasküler koruma sağlamada etkili araçlar olarak kabul edilir (28). Kısa vadede yüksek proteinli diyetlerin tüketilmesi böbrek iş yükünün artmasına ve GRH'de artışa neden olur. Bununla birlikte, normal böbrek işlevi veya hafif böbrek yetmezliği olan kişilerde protein alımının böbrek işlevleri üzerindeki uzun vadeli etkisi üzerine araştırmalar yetersizdir. Tip 2 diyabeti ve KBY olan bireylerde yapılmış bir çalışmada protein kısıtlamasının (yaklaşık 0.6-0.7 g/kg/gün) yararlı olabileceğini göstermektedir (29). Aslında, potein kısıtlaması olan diyetlerde böbrek işlevi, proteinüri, düşük dereceli inflamasyon ve oksidatif stresin azaldığı gözlemlenmiştir (29). Daha önce yapılan bir klinik çalışmada, yoğun diyabet tedavisinin albüminüriyi azalttığını gösterilmiştir. Azalan albüminüri, özellikle diabetesmellituslu hastalarda, KBH'nın daha yavaş ilerlemesi ile ilişkilidir (30). K/DOQI Kronik Böbrek Yetersizliğinde Beslenme için Klinik Uygulama Kılavuzunda, GRH $<25 \mathrm{~mL} /$ dakika/1.73 m² olduğunda, Evre 4-5 KBY hastalarında $0.6 \mathrm{~g} / \mathrm{kg} / \mathrm{gün}$ önerilmektedir. Bununla birlikte, diyet enerji alımının sürdürülememesi durumunda diyet protein alımı $0.75 \mathrm{~g} / \mathrm{kg} /$ gün'e kadar yükseltilebilir. Yapılmış çalışmalar, protein alımının günlük referans

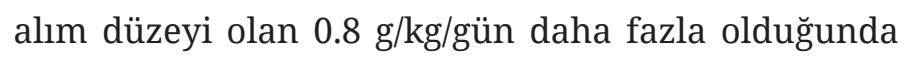


olumlu bir etkisi olmadığını, bu nedenle, yeterli miktarda elzem aminoasit sağlamak için Evre 1-3 KBY olan bireyler için protein gereksinmesinin $0.8 \mathrm{~g} /$ kg/gün olarak önerilmektedir. Ulusal Böbrek Hastalığı Eğitim Programı (NKDEP)'nin mevcut kılavuzları, aşırı diyet proteinini diyabeti olmayan kişilerde 0.8-1 $\mathrm{g} / \mathrm{kg} / \mathrm{gün}$ 'e ve diyabeti olan böbrek yetmezliği evre 1-3 KBY hastalarında, böbrek yetmezliğinin prognozun yavaşlatılabilmesi için $0.8 \mathrm{~g} / \mathrm{kg} /$ gün protein ile sinırlandirmasını tavsiye etmektedir (10).

Böbrek replasman tedavisi almayan $\mathrm{KBH}$ olan bireylerle yapılan araştırmalar, enerji gereksinmelerinin genel popülasyonla benzer olduğunugöstermektedir. Araştırmalar azot dengesini korumak, daha yüksek serum albümin düzeyi sağlamak, normal bir vücut bileşimini desteklemek ve protein kullanımını geliştirmek için yaklaşık 35 kkal/kg/gün sağlayan bir diyetin gerekli olduğunu göstermektedir. Fiziksel olarak sedenter olan Evre 1-3 60 yaş üstü $\mathrm{KBH}$ bireylerde $<30-35 \mathrm{kkal} / \mathrm{kg} /$ gün enerji alımı, Evre 460 yaş altı komorbid etmenleri olan KBY hastalarında 30 kkal/kg/gün enerji gereksinmesi uygun olabilir (31,32). Enerji gereksinmelerinin hesaplanmasinda Harris ve Benedict ve Schofield denklemleri gibi bazal metabolik hız tahmin denklemleri kullanılmaktadır. Tahmin denklemleri diyet planlama için başlangıç noktası olarak yararlı olabilirken, KBH'li bireylerin enerji gereksinmelerini yeterince tahmin edebilecek popülasyona özgü denklemler geliştirmek için daha fazla araştırma yapılması gerekmektedir (33). Protein ve enerji alımı için uygun, kişiye özel önerilerin belirlenmesinin anahtarı, hesaplamalar için kullanılan tahmini vücut ağırlığına dayanır. Gerçek vücut ağırlığı, diyalize edilmemiş hastadaki aşırı sıvı yükünü yansıtabilir ve potansiyel ağırlık kazanımına neden olabilir. Evre 4 KBY hastalarında ödemsiz ağırlığın belirlenmesi zor olabilir ve sıklıkla klinisyenin boy ve vücut ağırlığı geçmişine bağlı olarak tahmini veya istenen vücut ağırlığını kullanmasını gerektirir. KBY Evre 1-3 için enerji gereksinmeleri yaş, cinsiyet, fiziksel aktivite, beslenme durumu ve diğer komorbiditeler ile belirlenmektedir. Bunların dışında bireyin beslenme durumunun düzenli olarak izlenmesi ve enerji gereksinmelerine yönelik düzenlemeler yapılması önerilmektedir (32).

Obezite, dünyada artan bir sağlık sorunudur. Son dönem böbrek hastalığının ana nedenleri olan hipertansiyon ve Tip 2 diyabetin artmasına katkıda bulunur. Obez (BKI $\geq 30 \mathrm{~kg} / \mathrm{m}^{2}$ ) veya fazla kilolu (BKİ 25.0-29.9 kg/m²) bireylerin enerji gereksinmesi düzenlenmelidir. Orta derecede vücut ağırlığı kaybı (vücut ağırlığının \%7’si) ve düzenli fiziksel aktivite gibi yaşam tarzı değişiklikleri tedaviye uyarlanmalıdır (34-36).

KBH Evre 1-3 sırasında yüksek dislipidemi ve KVH prevalansı yüksektir. Dislipideminin kontrolü, GRH'deki düşüş oranını azaltabilmektedir. Az sayıda çalışmada, yağ modifikasyonunun $\mathrm{KBH}$ olan kişiler arasında KBH progresyonu üzerindeki etkileri araştırılmış olsa da Ulusal Kolesterol Eğitim Programı (NCEP) Yetişkin Tedavi Paneli (ATP III) Evre 1-3 KBY olan bireylere önerilebilir. ATP III, Düşük dansiteli lipoprotein (LDL) kolesterolü yüksek bireyler için doymuş yağ asitlerinin alımının enerjinin <\%7 düşürülmesini ve diyet kolesterol alımının <200 mg/gün'e düşürülmesini içeren tedavi edici yaşam biçimi değişiklikleri olarak adlandırılan yaşam tarzı yaklaşımını önerir. İlaç tedavisi başlamadan önce kolesterol kısıtlı diyet, toplam enerjinin yağdan gelen düzeyinin \%25-35, çoklu doymamış yağ asitlerin toplam enerjinin \%10, tekli doymamış yağ asitlerinin toplam enerjinin \%20 önermektedir. Karbonhidrat alımı, toplam enerjinin \%50-60's kadar olmalı ve çoğunlukla kompleks karbonhidratlardan zengin besinlerin tercih edilmesi, posa alımının günde 2030 g olması önerilmektedir (35-36). KVH insidansını azaltmak için epidemiyolojik ve klinik çalışmalarda omega-3 yağ asitleri kullanılmıştır. Epidemiyolojik çalışmalar, KVH riski taşıyan bireylerin, bitki ve deniz kaynaklı omega-3 yağ asitlerinin alımından yararlandığını göstermektedir. KBY Evre 1-3 olan bireylerde, omega-3 yağ asitleri yüksek olan besinlerin tüketmenin etkileri konusunda sinırlı araştırma olduğundan kılavuz önerileri yoktur. Uzun süreli omega-3 yağ asidi desteği kullanımı, KBH Evre 1-3 olan kişilerde titizlikle incelenmemiştir (23). 
Tablo 4. KBY evrelerine göre enerji ve besin ögesi gereksinmeleri (36)

\begin{tabular}{|c|c|c|c|}
\hline Evre & Açıklama & $\begin{array}{c}\text { GFH mL/ } \\
\text { dakika/ } \\
1.73 \mathrm{~m}^{2}\end{array}$ & Besin gereksinmesi \\
\hline 1 & $\begin{array}{l}\text { Normal GFH ile } \\
\text { böbrek hasarı } \\
\text { (idrarda protein } \\
\text { varlığı) }\end{array}$ & $>90$ & $\begin{array}{l}\text { Tavsiye edilen diyet önerileri } \\
\text { Enerji } 30-35 \mathrm{kkal} / \mathrm{kg} / \mathrm{gün} \\
\text { (35kkal <60 yaş, 30kkal> } 60 \text { yaş, Diyabet hastaları <30 kkal/kg/gün) } \\
\text { Suda çözünen vitaminler ve mineraller DRI önerileri }\end{array}$ \\
\hline 2 & $\begin{array}{l}\text { GFH'de hafif } \\
\text { düşüş ile böbrek } \\
\text { hasarı }\end{array}$ & $60-<89$ & $\begin{array}{l}\text { Düşük protein } 0.6 \text {-0.75 g/kg/gün } \\
\text { Enerji 30-35kkal/kg/gün } \\
\text { (35kkal <60 yaş, 30kkal > } 60 \text { yaş, Diyabet hastaları<30 kkal/kg/gün) } \\
\text { Fosfor } 800-1000 \mathrm{mg} \\
\text { Kalsiyumlu fosfat bağlayıcı içeren ajanlar ile kalsiyum 1000-1500 mg/gün } \\
\text { Sodyum <2.4 g/gün } \\
\text { Potasyum } 1 \mathrm{mEq} / \mathrm{kg} \\
\text { Kolesterol <200 mg/gün } \\
\text { Suda çözünen vitaminler ve mineraller DRI önerileri }\end{array}$ \\
\hline 3 & $\begin{array}{l}\text { GFH'de orta } \\
\text { derecede azalma }\end{array}$ & $30-59$ & $\begin{array}{l}\text { Düşük protein 0.6-0.75 g/kg/gün } \\
\text { Enerji 30-35 kkal/kg/gün } \\
\text { (35kkal <60 yaş, 30kkal > } 60 \text { yaş, Diyabet hastaları <30 kkal/kg/gün) } \\
\text { Fosfor } 800-1000 \mathrm{mg} \\
\text { Kalsiyumlu fosfat bağlayıcı içeren ajanlar ile kalsiyum 1000-1500 mg/gün } \\
\text { Sodyum <2.4g/gün } \\
\text { Potasyum 1mEq/kg } \\
\text { Kolesterol <200 mg/gün } \\
\text { Suda çözünen vitaminler ve mineraller DRI önerileri }\end{array}$ \\
\hline 4 & $\begin{array}{l}\text { GFH'de ciddi } \\
\text { azalma }\end{array}$ & $15-<30$ & $\begin{array}{l}\text { Düşük protein } 0.6 \text {-0.75 g/kg/gün } \\
\text { Enerji 30-35 kkal/kg/gün } \\
\text { (35kkal <60 yaş, 30kkal> } 60 \text { yaş, Diyabet hastaları <30 kkal/kg/gün) } \\
\text { Fosfor } 800-1000 \mathrm{mg} \\
\text { Kalsiyumlu fosfat bağlayıcı içeren ajanlar ile kalsiyum 1000-1500 mg/gün } \\
\text { Sodyum <2.4 g/gün } \\
\text { Potasyum } 1 \mathrm{mEq} / \mathrm{kg} \\
\text { Kolesterol <200 mg/gün } \\
\text { Suda çözünen vitaminler ve mineraller DRI önerileri }\end{array}$ \\
\hline 5 & $\begin{array}{l}\text { Böbrek } \\
\text { yetmezliği } \\
\text { (Son dönem } \\
\text { böbrek hastalığı) }\end{array}$ & $<15$ & $\begin{array}{l}\text { Konservatif tedavide düşük protein } 0.6 \mathrm{~g} / \mathrm{kg} / \mathrm{gün} \text {, diyaliz alan hastalarda } 1.2-1.3 \mathrm{~g} \text {, } \\
\mathrm{kg} / \text { gün } \\
\text { Fosfor } 800-1000 \mathrm{mg} \\
\text { Enerji } 30-35 \mathrm{kkal} / \mathrm{kg} / \mathrm{gün}(35 \mathrm{kkal} / \mathrm{kg} / \mathrm{gün}<60 \text { yaş, } 30 \mathrm{kkal} / \mathrm{kg} / \text { ün }>60 \text { yaş, Diyabet } \\
\text { hastaları }<30 \mathrm{kkal} / \mathrm{kg} / \mathrm{gün} \text { ) } \\
\text { Kalsiyum } 1000-1500 \mathrm{mg} / \mathrm{gün} \\
\text { Sodyum <2.4 g/gün } \\
\text { Potasyum } 1 \mathrm{mEq} / \mathrm{kg} \\
\text { Kolesterol <200 mg/gün } \\
\text { Suda çözünen vitaminler ve mineraller, DRI önerileri }\end{array}$ \\
\hline
\end{tabular}

\section{Sıvı ve elektrolit gereksinmesi}

Sodyum, hücre dışı bir elektrolit olarak sıvı dengesini düzenlemeye yardımcı olur. Sodyum filtrasyonu, idrar sıvı hacminde olduğu gibi KBY hastalarında azalır. Sodyum tutma kontrolü, sıvı tutulumu gerçekleştiğinde başlatılır. Evre 1-4 KBY hastalarında 
aldıkları sıvı ile çıkardıkları sıvı dengesinin sağlanması gerekir. İdrar çıkışı olmayan hemodiyaliz hastaları, aşırı sıvı yüklenmesini önlemek için sıvı kısıtlaması yapılmaktadır. Bu sıvı kısıtlaması, vücut ağırlığının yüzdesi kullanılarak veya bir hastanın kuru vücut ağırlığını (tüm ekstra sıvı alındığında, ideal olarak diyaliz sonrası ağırlık) kullanarak daha uygun bir şekilde hesaplanabilir. Periton diyalizi hastalarında tipik olarak sıvı tutulumu ile ilgili daha az sorun vardır, ancak diyalizat dekstroz düzeyinde değişiklikler gerektirebilir. Nakil hastalarında kullanılan ilaçlara ikincil olarak sodyum/sıvı tutma sorunları olabilir. Evre 1-4, Evre 5 hemodiyaliz ve periton diyalizi alan KBY hastalarında 2000 mg/ gün, transplantasyon hastalarında izlem ile sodyum eklemesi önerilmektedir. Sıvı alımı Evre 1-4 KBY hastalarında normal idrar çıkışı olduğu sürece normal alım olarak, Evre 5 hemodiyaliz hastalarında $1000 \mathrm{~mL} /$ gün + idrar çıkış miktarı kadar, Evre 5 periton diyalizi hastalarında izlemle 1500-2000 mL/gün, transplantasyon hastalarında kisıtlama verilmemektedir $(37,38)$.

Potasyum, hücre içi bir elektrolit olarak, kas kasılmalarında önemli bir rol oynar. Yüksek potasyum düzeyi (hiperkalemi) kalp atım hızının bozulmasına neden olabilmektedir. Evre 1-4 KBY hastalarinda laboratuvar bulgularına göre düzenleme yapılması, Evre 5 hemodiyaliz hastalarında 2000-3000 mg/ gün, Evre 5 periton diyalizi hastalarında 3000-4000 mg/gün, transplantasyon hastalarında kullanılan ilaçlara göre serum düzeyi kontrolü ve düzenlemesi önerilmektedir (38).

\section{Mikro besin ögeleri gereksinmesi}

Kemik bileşiminin korunması, böbrek hastalığında fosfor ve kalsiyum kontrolünün odak noktasıdır. Böbrek yetmezliği, normal böbrek işlevlerinde gastrointestinal sistemde fosfor ve kalsiyum emilimini kontrol eden D vitamini üretimini ve aktif kalsitriol 1,25(OH2)D3'e dönüşümünü azaltır. Sekonder hiperparatiroidizm ve paratiroid bezinin hiperplazisi, paratiroidhormon (PTH) düzeylerinin yükselmesi ve fosfor-kalsiyum feed-back mekanizmasinın hassasiyetini düşürmesiyle ortaya çıkar. K/DOQI kılavuzları hem diyet fosforunun hem de kalsiyumun kontrolüne odaklanmıştır. Diyetle fosfor kısıtlaması Evre 5 'te gereklidir, protein kaynaklarının genellikle fosfor içeriği yüksektir. Diyet dışı tedavi, dışkı atımını ve düşük bağırsak emilimini teşvik etmek için her bir ögenin fosfor içeriği ile oral fosfat bağlayıcılarının (alüminyum olmayan, magnezyum içermeyen) kullanımını içerir. Dolaşımdaki yüksek serum fosfor düzeyleri kemikten kalsiyum çekilmesini teşvik eder. Bazı fosfat bağlayıcıları, yumuşak doku kalsifikasyonuna katkıda bulunabilecek ve kardiyovasküler kalsifikasyon riskini arttırabilecek yüksek kalsiyum düzeyleri içerir. İntravenöz D vitamini hemodiyaliz tedavisi sirasinda veya periton diyalizinde oral tedavi ile uygulanabilir (39). Evre 1-4 KBY ve transplantasyon hastalarinda 1200 mg/gün, Evre 5 hemodiyaliz ve periton diyalizi hastalarında diyet ve ilaçlar dahil <2000 mg/gün kalsiyum, Evre 1-4 KBY laboratuvar bulgularına göre düzenleme, hemodiyaliz ve periton diyalizi hastalarında 800-1000 mg/gün önerilmektedir (38).

Yağda çözünen A ve $\mathrm{E}$ vitaminlerinin böbrek yetmezliğinde biriktiği bilinmektedir ve destek önerilmemektedir. Aşırı $\mathrm{K}$ vitamini, pıhtılaşma zamanını ve açık vasküler erişimi olumsuz yönde etkileyebilmektedir. Bazı suda çözünen vitaminlerin günlük gereksinmesinin, özellikle potansiyel diyalizat kaybıyla birlikte KBY'de arttığ vitamini, $\mathrm{B}_{12}$ vitamini, gibi protein metabolizmasında rol oynayan vitaminleri azalttığı gösterilmiştir. Folik asit, intravenöz eritropoetin (böbrek yetmezliğinde bozulmuş hormonun yapay versiyonu) ve demir ile birlikte kırmızı kan hücresi üretimini arttırır. Araştırmalar homosisteinin KBY'de arttığını ve bu popülasyonda görülen kardiyovasküler riske katkıda bulunan bir etmen olabileceğini göstermiştir (38). C vitamini gereksinmesi, böbrek yetmezliği olan kişilerle aynıdır, aşırı düzeyler, normal böbrek işlevi olan risk altındaki hastaların bir alt grubunda artmış kalsiyum oksalat böbrek taşı oluşum insidansı ile ilişkilendirilmiştir. Çinko azalmış tat duyusu ile ilişkilendirilmiştir. Besin ögesi desteği, semptomlar 
ve serum düzeylerinin izlenmesi ile birlikte dikkatli bir şekilde yapılmalıdır. KBH hastaları genellikle yeterli kırmızı kan hücresi üretememeleri nedeniyle anemiktir ve Evre 5'ten önce deri altından yapay eritropoietin alabilir. Transferrin doygunluk yüzdesi bu hastalarda genellikle demir yükünün bir göstergesi olarak kullanılır ve hem bolus hem de kronik demir desteğinin belirlenmesinde yararlı olabilir (39).

\section{SONUÇ VE ÖNERILER}

GFH'de düşüş diyaliz, kardiyovasküler hastalık, hipertansiyon, anemi ve diğer metabolik komplikasyonları içeren komplike böbrek yetmezliği riskiileilişkilidir.Erkendönemdefarkındalığınındüşük olması, global olarak bulaşıcı olmayan önlenebilir hastalıkların prevalansının artması ile önemli bir halk sağlığı sorunu olmaktadır. Progresif ilerleyici bir yapısı olması nedeni ile sağlık harcamalarında yüksek maliyete neden olmaktadır. Akut ve kronik böbrek yetmezliğinin tıbbi tedavisinin bir parçası olan tıbbi beslenme tedavisi ile böbrek yetmezliğinin progresyonun yavaşlatılması, malnütrisyonun önlenmesi, inflamasyonun azaltılması, mortalite ve morbiditenin düşmesi sağlanırken hastaların yaşam kalitelerinin korunması ve/veya geliştirilmesi sağlanmaktadır. Böbrek yetmezliğinin tıbbi beslenme tedavisi uzmanlık gerektiren diyet bileşenlerinden oluşmaktadır ve diyetisyenlerin de içinde olduğu bir tedavi ekibi ile yürütülmelidir. Hastanın beslenme durumu saptaması ile beslenme müdahalesi başlarken, hastanın beslenme eğitimleri ve izlemleri ile devam etmektedir. En etkin sonuçlar hastanın beslenme müdahalesi ve tedavisine sağladığı uyum ile elde edilebilmektedir.

Çıkar çatışması - Conflict of interest: Yazarlar çıkar çatışması olmadığını beyan ederler. - The authors declare that they have no conflict of interest.

\section{KAYNAKLAR}

1. U.S. Renal Data System. USRDS 2013 Annual data report: Wilson BL. Renal physiology. In: Othersen BJ, Thomas
KL, editors. Nutrition Therapy for Chronic Kidney Disease. NW: Taylor \& Francis Group; 2012. p. 15-31.

2. Hill NR, Fatoba ST, Oke JL, Hirst JA, O’Callaghan CA, Lasserson DS, Hobbs FDR.Global prevalence of chronic kidney disease - A systematic review and meta-analysis. PLoS ONE 2016;11:0158765.

3. Suleymanlar G, Utas C, Arinsoy T, Ates K, Altun B, Altiparmak MR, et al. A population-based survey of chronic renal disease in Turkey-The CREDIT Study. Nephrol Dial Transplant 2011;26:1862-71.

4. Irmak H, Sucaklı BM,Yardım N, Keklik K.Türkiye Böbrek Hastalıkları Önleme ve Kontrol Programı Eylem Planı 2014-2017. Ankara:T.C. Sağlık Bakanlığı Halk Sağlığı Kurumu; 2014.

5. Bilgiç A, Akçay A, Sezer S. Akut böbrek hasarında beslenme desteği. Turk Neph Dial Transpl 2013;22(1):715.

6. Kathuria P, Khurana A. Acute kidney Injury. In: Othersen JB, Thomas LK. editors. Nutrition Therapy for Chronic Kidney Disease. NW: Taylor \& Francis Group; 2012. p.55-73.

7. Nash K, Hafeez A, Hou S. Hospital-acquired renal insufficiency. Am J Kidney Dis 2002;39(5):930-6.

8. Druml W. Nutritional support in acute renal failure. In: Ikizler TA, Mitch WE, editors. Handbook of Nutrition and the Kidney. 6th ed. Philadelphia: Lipincott Williams \& Wilkins; 2010. p.72-91.

9. Zappitelli M, Goldstein SL, Symons JM. Protein and calorie prescription for children and young adults receiving continuous renal replacement therapy: A Report From The Prospective Pediatric Continuous Renal Replacement Therapy Registry Group. Crit Care Med 2008;28:3239-45.

10. KDOQI members. KDOQI Clinical practice guidelines for nutrition in chronic renal failure: protein intake during acute illness Guideline 20. AJKD 2000;35(Suppl 2):51.

11. Obialo CI, Okonofua EC, Nzerue MC, Tayade AS, Riley LJ. Role of hypoalbuminemia and hypocholesterolemia as copredictors of mortality in acute renal failure. Kidney Int 1999;56(3):1058-63.

12. Saxena A. Dietary management in acute kidney injury. Clinical Queries: Nephrology 2012;1:58-69.

13. Scheinkestel CD, Kar L, Marshall K. Prospective randomized trail to assess calorie and protein needs in critically ill, anuric, ventilated patients requiring calorie and protein needs in critically ill, anuric, ventilated patients requiring. Nutrition 2003;19:909-16.

14. McCarthy MS, Phipps SC. Special nutrition challenges: Current approach to acute kidney injury. Nutr Clin Pract 2014;29:56. 
15. Macias WL, Alaka KJ, Murphy MH. Impact of the nutritional regimen on protein catabolism and nitrogen balance in patients with acute renal failure. J Parenter Enteral Nutr 1996;20:56-62.

16. Fiaccadori E, Maggiore U, Rotelli C. Effects of different energy intakes on nitrogen balance in patients with acute renal failure: A pilot study. Nephrol Dial Transplant 2005;20:1976-80.

17. Moore PK, Hsu RK, Liu KD. Management of acute kidney injury: Core Curriculum 2018. Am J Kidney Dis 2018;1:72-80.

18. Berbel MN, Pinto MPR, Ponce D, Balbi A. Nutritional aspects in acute kidney injury. Rev Assoc Med Bras 2011;57(5):587-92.

19. Chioléro R, Berger MM. Nutritional support during renal replacement therapy. In: Bellomo R, Kellum JA, Ronco C, editors. Acute Kidney Injury: Contrib Nephrol; 2007. p. 267-74.

20. Shafi T, Coresh J. Chronic kidney disease: definition, epidemiplogy, cost, and outcomes. In: Sayegh $\mathrm{MH}$, Himmelfarb J, editors. Chronic Kidney Disease, Dialysis, and Transplantation. 3rd ed. Philadelphia: Saunders; 2010. p. 3-21.

21. Wilkens KG, Juneja V. Shanaman E. Medical nutritional therapy for renal disorders.In: Edcott-Stump S, Raymond J, Mahan LK, editors. Krause's Food and The Nutrition Care Process. 13th ed. Missouri: Elsevier; 2012. p. 799831.

22. Çalışkan Y, Yıldız A. Kronik böbrek hastalığında beslenme desteği. İç Hastalıkları Dergisi 2010;17:247-56.

23. Levey AS. The definition, classification, and prognosis of chronic kidney disease: a KDIGO Controversies Conference Report. Kidney Int 2017;80(1):17-20.

24. Stote SK. Nutrition for chronic kidney disease, Stages 1-3. In: Othersen J.B Thomas K.L, editors. Nutrition Therapy for Chronic Kidney Disease. NW:Taylor \& Francis Group; 2012. p. 109-23.

25. Kopple J. National kidney foundation K/DOQI clinical practice guidelines for nutrition in chronic renal failure. Am J Kidney Dis 2001;31:954-61.

26. Thomas KL. Brief history of kidney disease. In: Othersen JB, Thomas KL, editors. Nutrition Therapy for Chronic Kidney Disease. NW:Taylor \& Francis Group; 2012. p. 1-15.

27. Bellizzi V, Cupisti A, Locatelli F, Bolasco P, Brunori G, Cancarini G, et al. Low-protein diets for chronic kidney disease patients: the Italian experience. BMC Nephrology 2016;17:77.

28. Ameh OL, Cilliers L, Okpechi IG. A practical approach to the nutritional management of chronic kidney disease patients in Cape Town, South Africa. BMC Nephrology 2016;17:68.

29. Mitch WE, Remuzzi G. Diets for patients with chronic kidney disease, still worth prescribing. J Am Soc Nephrol 2004;15(1):234-7.

30. Giordano M, Ciarambino T, Castellino P, Cataliott A, Malatino L, Ferrara N, et al. Long-term effects of moderate protein diet on renal function and low-grade inflammation in older adults with type 2 diabetes and chronic kidney disease. Nutrition 2014;1045-9.

31. Hemmelgarn BR, Manns BJ, Lloyd A. Relation between kidney function, proteinuria, and adverse outcomes. JAMA 2010;303(5):423-9.

32. Kopple J. National kidney foundation K/DOQI clinical practice guidelines for nutrition in chronic renal failure. Am J Kidney Dis 2001;1:66-70.

33. National KidneyFoundation. KDOQI Clinical Practice Guidelines for Nutrition in Chronic Renal. Am J Kidney Dis 2000;1:1-104.

34. Kamimura MA, Avesani CM, Bazanelli AP, Baria F, Draibe SA, Cuppari L. Are prediction equations reliable for estimating resting energy expenditure in chronic kidney disease patients? Nephrol Dial Transplant 2011;26:544-50.

35. Kopple J. Obesity and chronic kidney disease. J Renal Nutr 2010;20:29-30.

36. Expert Panel on Detection, Evaluation, and Treatment of High Blood Cholesterol in Adults. Executive summary of The Third Report of National Cholesterol Education (NCEP) Expert Panel on Detection, Evaluation, and Treatment of High Blood Cholesterol in Adults (Adult Treatment Panel III). JAMA 2001;285:2486-97.

37. Saxena A. Nutritional problems in adult patients with chronic kidney disease. Clinical Queries Nephrology 2012;1:222-35.

38. Kopple JD. National Kidney Foundation K/DOQI clinical practice guidelines for nutrition in chronic renal failure. National Kidney Foundation 2001;37:66-70.

39. Beto JA, Bansal KV. Medical nutrition therapy in chronic kidney failure: integrating clinical practice guidelines. J AcadNutrDiet 2004;104(3):404-9. 